\title{
39S Ribosomal Protein L45, Mitochondrial
}

National Cancer Institute

\section{Source}

National Cancer Institute. 39 S Ribosomal Protein L45, Mitochondrial. NCI Thesaurus. Code C102974.

$39 \mathrm{~S}$ ribosomal protein $L 45$, mitochondrial (306 aa, $\sim 35 \mathrm{kDa}$ ) is encoded by the human MRPL45 gene. This protein is involved in mitochondrial gene product expression. 